\title{
Village Government Policy Towards International Investment
}

\author{
Nitaria Angkasa ${ }^{1 *} \quad$ Yuswanto $^{2} \quad$ Budiyono $^{2}$ \\ 1.Students of the Doctoral Study Program in Law, Universitas Lampung, Bandar Lampung, Indonesia \\ 2.Lecturer of Faculty of Law, Universitas Lampung, Bandar Lampung, Indonesia
}

International Seminar on Foreign Investment Law in Indonesia-Muhammadiyah University Metro-28 October 2021

\begin{abstract}
The important task of the Village Government is to provide administrative services in the form of correspondence to the citizens, from this, the village government has opportunities in the form of village policies and regulations to be able to increase the potential of the village through international investment by modeling local government policies and regulations. The result of the research is that the Village Government can issue policies and regulations based on the authority of each village government, as well as increasing economic potential through international investment in the Influence of Village Government Policy in International Investment Growth in Indonesia, namely through shifting regulations on villages, By looking at the current regulations, the authority of the village head is limited to the procedures that must be met to implement international investment. The obstacles of village government in policy makers to investment are caused by several factors, including the weak role of village institutions in welcoming existing changes. It is necessary to strengthen the village first so that policies in international investment can work well.
\end{abstract}

Keywords: Policy, Village Government, International Investment

DOI: $10.7176 / \mathrm{JLPG} / 115-02$

Publication date: November $30^{\text {th }} 2021$

\section{Introduction}

Village government has existed since the days before Indonesia's independence, every development has a change in the regulations, nowadays it is often talk that villages in Indonesia are influenced by the otonimi system known as the village autonomy system. The policy of the village government is seen from its structure and authority, then the structure and authority are based on the regulations and policies of the village that are in force.

Village policy can be studied from the applicable regulations that start from before Indonesia was independent, namely the Dutch colonial era, but the application of village regulations specifically is through Law 5 of 1979 on village government, where the authority of the village at that time in the sub-district, and this is standardized by all villages in Indonesia, After that the change to Law No. 22 of 1999 that the authority is addressed to the region, the change after Law no. 22 of 1999, namely Law No. 32 of 2004 that remains to the local government and is held by the village supervisor, so that the head of state has no breadth in using policies against the village government. ${ }^{1}$

The notion of villages sourced from not uniform or diverse to uniform in law regulation 5/1979 is called jawanization, meaning that for villages outside Java applied the same as the existing government in Java, indirectly villages outside Java are not recognized its existence and the right asl proposal of the village is applied the same as the existing government in Java, indirectly villages outside Java are not recognized its existence and the right asl proposal from the village. The authority of the village government is seen to have no broad authority in shaping policies to implement the potential of the village in their respective village communities.

Based on Law 5/1979 the leadership of the Village Head is not a leader in village government for the village community, only the extension of the local government, which in this case is the subdistrict, while we know the subdistrict is part of the local government that is responsible for the regional head, the power of the village is decreasing, so that the local government can provide policy to the village community.

Based on Law 5/1979 the village government structure can be described in the reform of power in carrying out village government, namely village kepa coupled with the Village Deliberation Institution (LMD), but the division of power is only limited to the picture in the village only, for its duties and functions remain subject to local government, namely the village head does not have full authority over the formation of policies or laws and regulations in the village. ${ }^{2}$

Based on the different picture in village laws and regulations in Law 22/1999, decentralization travel can already be seen in Law 22/1999. The difference between each village has been raised in this village regulation, there is a change in the authority of each village recognized in this legislation towards self-government in

${ }^{1}$ Oleh Irine H Gayatri, ‘Demokrasi Lokal (Di Desa): Quo Vadis? Oleh Irine H. Gayatri', April 2007, 2004.

${ }^{2}$ E.B. Sitorus and others, 'Naskah Akademik Rancangan Undang-Undang Tentang Desa', Naskah Akademik Rancangan Undang-Undang, 2007, 1-98<www.forumdesa.org >. 
running a self-governing community-based government.

The form of village government has been seen with the division of power, that there is a Village Representative Agency (BPD) that has the authority as the controller of village policy, BPD as part of the village government to spread the culture and customs that exist in each village in this Country of Indonesia. BPD is also a reservoir for the aspirations of the village community, but the policy also illustrates the limitations of the village government policy, that the village government remains limited in its authority over local government. The village government still cannot implement and make full policy and explore the potential that exists in the village both in terms of economy, development, industry, and trade with foreign parties let alone establish cooperation to support international investment in the village.

Changes to village regulations to Law 32/2004, there is a division of power as in the previous village government regulations in the concept of regional autonomy and does not generalize the existence of village autonomy in it, villages are not entitled to issue policies against customary potential and wide origin rights, Because the policy is still limited to local government, so the development of village government cannot play a role in economic development with foreign parties or to form policies in international investment.

Based on Article 206 of Law 32/2004 there are rules on the division of affairs for the village including stewardship regarding village government, stewardship in the origin of villages that have developed since long ago, there is stewardship of local government that has been delegated to the village government and other irregularity that has been determined in the law.

Based on changes in existing village legislation, Indonesia is currently heading to the village government which is often referred to using the village autonomy system, meaning that the village government has a policy in implementing the potential of village communities based on the village autonomy system. The village government cannot be abandoned its role as part of the Indonesian state, as well as in the development of international investment.

Improving a country's economy is the task of government and people, a country's economy can be done from various fields, and one of them is the increase in international investment in Indonesia in the form of trade, industry, mining and tourism. International investment has very important benefits to introduce tourism and products from the Country of Indonesia and improve the economy of the country. ${ }^{1}$

The increase in international investment will not be carried out without the support of the government, both the central government, local government and village government, the synergy of each government is seen from the duties of their respective functions and authorities, for the central and local governments already running for policies towards international investment, but for village governments there is still rarely talk and thought about policies on international investment.

As local governments understand to improve the economy, there are local governments that understand there are sectors that can be developed to generate profits with the creation of investment, the benefits that we can get are increasing income for the community, also local governments can jump in to increase cooperation with foreign parties and local governments formulating in accordance with the potential of the area in the form of legislation. so that the potential of the area can develop

Seeing the role of local governments that also began to develop international investment in increasing regional potential, the Village Government as the lowest level of government in the country of Indonesia, also has the role and authority to increase the potential of the village. The village becomes the closest political arena for the relationship between the community and the holder of power, namely the village device, so as the government in its community closest to the community should better understand the area and potential that exists in the village, The proximity of the village government to the community can be seen from the village devices to be part of the state bureaucracy that has a list of government tasks, namely carrying out bureaucratization at the village level, implementing development programs, providing administrative services to the community. The important task of the Village Government is to provide administrative services in the form of correspondence to the citizens, from this, the village government has opportunities in the form of village policies and regulations to be able to increase the potential of the village through international investment by modeling local government policies and regulations.

\section{Research Method}

Normative juridical research based on documents, laws and regulations, judges' rulings, and others related to village government policies in exploring the potential of villages to cooperate with foreign parties to develop the village economy through international investment. Empirical Juridical research of the objects studied is the village policy that negates the village autonomy system in shaping the policy of desala expansion towards international investment related to the aspect of society. ${ }^{2}$ Therefore, this research is further referred to as

\footnotetext{
${ }^{1}$ Aprilia Nesia, Sofia Pangemanan, and Stefanus Sampe, 'PERAN PEMERINTAH DAERAH DALAM MENINGKATKAN INVESTASI (Studi Kasus PT. Conch North Sulawesi Cement)', 3 (2019), 1-10.

${ }^{2}$ Bambang Sunggono, Penelitian Hukum (Jakarta: PT Raja Grafindo Persada, 2003). p. 43.
} 
Sociological Legal Research. ${ }^{1}$ This research aims to form a picture of village government policy to explore the potential of villages towards international investment. Researchers collect data from legislation and news and combine with legislation.

Socio-legal is a combination of various sciences, both political, economic, cultural, history, anthropology, communication and other sciences further combined in legislation, legal principles and a number of other sciences, combined in science.

\section{Discussion}

A. Village Government as part of the Indonesian Unity of Government for the Implementation of International Investment.

The village as the smallest community unity in the Indonesian state has authority as a government, because in it there is authority to share affairs to be able to be responsible for the village community as with, changes in village regulations indicate that the role of village government is very important in structuring the implementation of village government to maintain and maintain the welfare of the village community. Village government is the government closest to the community that each village has the potential and right of origin of potential that exists in the government itself. strengthening of the village through Law 6/2014. Accompanied by Government Regulation No. 47 of 2015 concerning villages which is one of the implementing regulations for the Village Law, for the development of village governance, thus the village government has full authority to form village policies in increasing the potential of villages for international investment that has been carried out by local governments. shaping international investment policies, then the village government can take part in international investment through village policies and government in each village in accordance with the potential and origin rights of each village to improve the economy and village development, but in the current era, there is a shift in the implementation of government administration. The village seems to have shifted. This shift can be seen from national characteristics to modern characteristics in the administration of village governance, namely previously nationally uniform village characteristics then shifted to the end of village uniformity in view of village origin rights (modern characteristics). The importance of the role of government in Indonesia as a unitary state is also in the sense of having a role that is no less important than the central government and local governments in the implementation of international investment.

Speaking of village government, not only recently, but since the Dutch colonial era, there has been a shift in village government which often undergoes changes such as, the amendment to the Village Regulation, leading to a shift in the function of the village bureaucracy, such as the Amendment to Article 5 paragraph (1) and Article 20 of the 1945 Constitution in the Indonesian presidential system, the shift in question is the transition or transfer of the legislative function as a result of the amendments to Article 5 paragraph (1) and Article 20 of the 1945 Constitution. $^{2}$

Constraints in policy will always exist, so the implementation of village government really must be managed from the division of affairs in the village government, and all play a good role from the government in the running authority of the village government and controlling the village government policies so that the policy in international investment can be implemented. well. ${ }^{3}$

Changes in village regulations in Indonesia are currently known as village autonomy, meaning that villages have the authority to manage their own territory based on potential authority in regulating government affairs, regions and developing village potential by issuing policies and regulations based on the authority of each village government, also increasing economic potential through international investment. ${ }^{4}$

B. The Influence of Village Government Policies on International Investment Growth in Indonesia

Village government affects the composition of life in the community in the village unit, the village government needs to play a role in policies for the sustainability of the village's potential, because it will affect village problems, improve the economy and human resources, with technological developments and the current era we know how the extraordinary potential that exists in each village in Indonesia today, both from the culture and diversity of arts that exist in the village to play a role in shaping international investment policies. ${ }^{5}$ Strengthening village potential can be determined in its entirety from aspects around the village, village regulations, village communities, village assets, village development, all of which are determined by the role of the village government in its policies towards improving community welfare.

The development of life in the community is growing, from technology and the economy, so the village government must be able to facilitate through policies to improve services to the community both for internal

\footnotetext{
${ }^{1}$ Soerjono Soekanto, Pengantar Penelitian Hukum (Jakarta: UI Press). p.51.

${ }^{2}$ Saldi Isra, Pergeseran Fungsi Legislasi (Depok: Pt. Rajawali Pers, 2018). p.20.

${ }^{3}$ Ismail Sunny, Pergeseran Kekuasaan Eksekutif (Jakarta: Aksara Baru, 1986). p. 84-85.

${ }^{4}$ Muhamad Ilwan, Galang Asmara, and Iwan Permadi, 'The Form of the Village Government on Autonomy Era of Village in Indonesia', 53.6 (2016), 198-204

${ }^{5}$ Ateng Syafrudin dan Suprin Na'a, Republik Desa, Pergulatan Hukum Tradisional Dan Hukum Modern Dalam Desain Otonomi Desa, 2010.
} 
and external parties. ${ }^{1}$ As a government, the village government through its structure and with village authority has changed, currently the village government has a village autonomy system, so that the village government can participate in improving the economy by starting to form international investment policies in the form of tourism, culture, industry. Thus encouraging the welfare of the community as the main target of the government ${ }^{2}$

Development and the economy as a main target of the government, the village government as part of the Indonesian government with a village autonomy system, the village government has the right to make policies in the implementation of international investment in the fields of tourism, industry, and trade in the village, ${ }^{3}$ because of the tie government in it. village bureaucracy in community service for the role of village government in increasing international investment. ${ }^{4}$

Article 24 of Law 6/2014 explains the explanation of the process of administering village government with the principle of legal certainty, thus clarity regarding the authority in administering village government, the basis for administering village government based on legal certainty following developments with international investment can be carried out with legislation and policies that made by the village government based on the authority of the village autonomy system by looking at the principle of legal certainty, orderly administration of government, orderly public interest, openness, proportionality, professionalism, accountability, effectiveness and efficiency, local wisdom, diversity, participatory.

National development by the central government and local governments have issued international investment policies, so that international investment has been implemented. This condition is a form of government regulation, then the form of village government regulation by fostering international investment in villages with village regulations will have an impact as a driver of village economic stability which is also a driving force economic stability and national development. ${ }^{5}$ Stakeholders want to see how the dynamics of village development are currently, with the presence of Law $6 / 2014$, especially in terms of managing village finances as a result of the effect of providing village funds which are increasingly large in number by the Central Government. Although it shows that the Government is serious in encouraging and advancing the village as a central grassroots to support national development. ${ }^{6}$

The shift in village regulations, also affects the village bureaucracy as a work unit in the village, which was previously unstructured to be structured, this can be seen with the work unit that was previously focused on the full power of the village head over all fields in the village, by looking at the regulations Currently, the village head's authority is limited to procedures that must be met, for example, previously the village head could appoint village officials with full authority from the village head, but currently they have to go through village apparatus test test procedures, for example the village head and his apparatus must also prepare The procedure for reporting village performance begins with making regulations in the form of village regulations, village regulations that have shifted in structure and looking at examples from local governments to improve the economy and village potential must be able to compete to open up opportunities to develop village policies and regulations in participating in growing international investment. international in the village.

C. Inhibiting Factors for Village Government in making policies on international investment

The implementation of international investment in villages is not easy to implement, therefore an assessment of regulations on international investment in villages can start from the village bureaucracy. the new model, namely with the experience of the organization he has chosen to guide, the principle will solve the major problems experienced with bureaucratic government ${ }^{7}$

The ten principles are catalytic governance, community-owned governance, competitive governance, mission-driven governance, results-oriented governance, customer-oriented governance, entrepreneurial governance, anticipatory governance, decentralized governance, market-oriented governance. ${ }^{8}$

The ten principles mentioned above require a strategy for transforming the organizational system, namely core strategy, consequence strategy, customer strategy, control strategy, cultural strategy. ${ }^{9}$

\footnotetext{
1 Made Arie Wahyuni Ni Komang Yoni Rahayu, Ni Kadek Sinarwati, 'Analisis Pengaruh Profesionalisme Pengelolaan Keuangan Daerah, Pemanfaatan Teknologi Informasi, Dan Pengendalian Internal Terhadap Kualitas Laporan Keuangan Pada Dinas Pendapatan Daerah Kabupaten Gianyar', E-Journal S1 Ak Universitas Pendidikan Ganesha Jurusan Akuntansi Program S1, 8 No 2 (2017).

${ }^{2}$ Dwi Priyanti, 'Sistem Informasi Data Penduduk Pada Desa Bogoharjo Kecamatan Ngadirojo Kabupaten Pacitan', IJNS - Indonesian Journal on Networking and Security, 2013.

3 jumaiyah dan Wahidullah, 'PEMBENAHAN PENGELOLAAN KEUANGAN DANA DESA: STUDI KASUS DESA SENGONBUGEL', Media Riset Akuntansi, Auditing \& Informasi 19, 19.1 (2019), 19-34.

${ }^{4}$ Wawan Risnawan, 'Profesionalisme Perangkat Desa Dalam Pengelolaan Keuangan Desa', Dinamika: Jurnal Ilmiah Administrasi Negara, $6.2(2016), 50-56$

5 Jumaiyah Jumaiyah and Wahidullah Wahidullah, 'Pembenahan Pengelolaan Keuangan Dana Desa: Studi Kasus Desa Sengonbugel', Media Riset Akuntansi, Auditing \& Informasi, 19.1 (2019), 19 <https://doi.org/10.25105/mraai.v19i1.3307>.

${ }^{6}$ et al. Ferina, Sasti Ika., 'Efektivitas Realisasi Dan Serapan Anggaran Pendapatan Dan Belanja Daerah Pada Pemerintah Kabupaten Ogan Komering Ilir Tahun 2013-2015', Jurnal Ilmiah Manajemen Bisnis Dan Terapan, 2, 2016, $73-88$.

${ }^{7}$ David Osborn dan ted Gebler, Mewirausahakan Birokrasi Reinventing Goverbment (Jakarta: PT.PPM, 2017 ). p. 22.

${ }^{8}$ Gebler.p. 29-311.

${ }^{9}$ David Osborn dan peter Plastrik, Memangkas Birokrasi (Jakarta: PT. PPM, 2018).p. 77-236.
} 
Discussion of the paradigm of the village apparatus bureaucracy with the new system being able to compete in the form of policies and regulations at the village government to be able to prevent problems with problems that arise in the implementation of village policies and regulations in the implementation of international investment in villages.

Efforts to strengthen the village ${ }^{1}$. always experience many problems, obstacles and dilemmas. This is due to several factors, including the weak roles of village institutions in welcoming the existing changes. It is necessary to strengthen the village first so that policies in international investment can run well. Some reform and rearrangement efforts from the old spirit and rules to the new spirit and rules have not been completely smooth. ${ }^{2}$ Increasing the village bureaucracy in village government is really needed to provide policies and regulations on international investment in villages, thus the potential in the village as the smallest community area is easy to achieve economic potential in Indonesia.

The village as a forum for a unitary government, it is very important to make special regulations in the village to develop international investment in promoting the welfare of rural communities and to maintain the principle of recognition and origin rights of village government, so that these regulations form the form of the existence of village government. So far, the authority for formulating regulations in the village has always had the involvement of the central government, the DPR and DPRD, so that the authority of the village government is limited. The village seems to be the composition of the regional government, while the village also has village autonomy to make policies and regulations in the village, so the capacity of the village bureaucracy is improved. quality and policies will also affect the level of international investment. The data shows that most areas in Indonesia are rural, which is 83.2 percent with rural data of 74 thousand villages. Underdeveloped villages still dominate Out of 74 thousand, ${ }^{3} 45$ percent or around 32,500 villages are underdeveloped (poor) ${ }^{4}$ villages. Based on these data, changes to achieve potential through international investment must be improved in achieving village goals, namely increasing development potential and the economy.

\section{Conclusion}

The conclusion of this writing discussion is:

1. Village Administration as part of the Indonesian Government Unity for the Implementation of International Investment with Changes in village regulations in Indonesia is currently known as village autonomy, meaning that the village has the authority to manage its own territory based on potential authority in regulating government affairs, regions and developing village potential by issuing policies and regulations based on the authority of each village government, also increasing economic potential through international investment

2. The influence of village government policies on the growth of international investment in Indonesia, namely through the shift in village regulations, also affects the village bureaucracy as a work unit in the village, which was previously unstructured to become structured, this can be seen with work units that were previously focused on full power the village head towards all fields in the village, by looking at the current regulations the village head's authority is limited to the procedures that must be met to implement international investment.

3. Barriers to village government in policy makers towards international investment, namely by strengthening villages. ${ }^{5}$ always experience many problems, obstacles and dilemmas. This is due to several factors, including the weak roles of village institutions in welcoming the existing changes. It is necessary to strengthen the village first so that policies in international investment can run well. Some reform and rearrangement efforts from the old spirit and rules to the new spirit and rules have not been completely smooth. ${ }^{6}$ Increasing the village bureaucracy in village government is really needed to provide policies and regulations regarding international investment in villages, thus the potential in the village as the smallest community area is easy to achieve economic potential in Indonesia.

\section{References}

'Badan Pusat Statistik' <https://www.bps.go.id/pressrelease/2018/12/10/1536/hasil-pendataan-potensi-desa-podes--2018.html $>$ [accessed 2 October 2021]

Ferina, Sasti Ika., et al., 'Efektivitas Realisasi Dan Serapan Anggaran Pendapatan Dan Belanja Daerah Pada

${ }^{1}$ Andin Sofyanoor, 'Pengaturan Desa Dalam Perspektif Law As an Allocative System', FIAT JUSTISIA:Jurnal Ilmu Hukum, 8.2 (2015), 221-41<https://doi.org/10.25041/fiatjustisia.v8no2.293>

${ }^{2}$ HAW.Widjaja, Otonomi Desa Merupakan Otonomi Yang Asli, Bulat Dan Utuh (Jakarta: PT. Raja Grafindo Persada, 2008).p. 4.

${ }^{3}$ Badan Pusat Statistik'<https://www.bps.go.id/pressrelease/2018/12/10/1536/hasil-pendataan-potensi-desa--podes--2018.html> [accessed 2 October 2021].

4 Kata Kunci, 'Diringkas Dari Soetandyo Wignosubroto Dkk , Pasang Surut Otonomi Daerah:Sketsa Perjalanan 100 Tahun , Institute for Local Development, Yayasan Tifa, Jakarta,2005', 27, 2005.

${ }^{5}$ Sofyanoor.

${ }^{6}$ HAW.Widjaja. p.4. 
Pemerintah Kabupaten Ogan Komering Ilir Tahun 2013-2015', Jurnal Ilmiah Manajemen Bisnis Dan Terapan, 2, 2016, 73-88

Gayatri, Oleh Irine H, 'Demokrasi Lokal (Di Desa): Quo Vadis? Oleh Irine H. Gayatri', April 2007, 2004

Gebler, David Osborn dan ted, Mewirausahakan Birokrasi Reinventing Goverbment (Jakarta: PT.PPM, 2017)

HAW.Widjaja, Otonomi Desa Merupakan Otonomi Yang Asli, Bulat Dan Utuh (Jakarta: PT. Raja Grafindo Persada, 2008)

Ilwan, Muhamad, Galang Asmara, and Iwan Permadi, 'The Form of the Village Government on Autonomy Era of Village in Indonesia', 53.6 (2016), 198-204

Isra, Saldi, Pergeseran Fungsi Legislasi (Depok: Pt. Rajawali Pers, 2018)

Jumaiyah, Jumaiyah, and Wahidullah Wahidullah, 'Pembenahan Pengelolaan Keuangan Dana Desa: Studi Kasus Desa Sengonbugel', Media Riset Akuntansi, Auditing \& Informasi, $19.1 \quad$ (2019), 19 $<$ https://doi.org/10.25105/mraai.v19i1.3307>

Kunci, Kata, 'Diringkas Dari Soetandyo Wignosubroto Dkk, Pasang Surut Otonomi Daerah:Sketsa Perjalanan 100 Tahun, Institute for Local Development, Yayasan Tifa, Jakarta,2005', 27, 2005

Na'a, Ateng Syafrudin dan Suprin, Republik Desa, Pergulatan Hukum Tradisional Dan Hukum Modern Dalam Desain Otonomi Desa, 2010

Nesia, Aprilia, Sofia Pangemanan, and Stefanus Sampe, 'PERAN PEMERINTAH DAERAH DALAM MENINGKATKAN INVESTASI (Studi Kasus PT. Conch North Sulawesi Cement)’, 3 (2019), 1-10

Ni Komang Yoni Rahayu, Ni Kadek Sinarwati, Made Arie Wahyuni, 'Analisis Pengaruh Profesionalisme Pengelolaan Keuangan Daerah, Pemanfaatan Teknologi Informasi, Dan Pengendalian Internal Terhadap Kualitas Laporan Keuangan Pada Dinas Pendapatan Daerah Kabupaten Gianyar', E-Journal S1 Ak Universitas Pendidikan Ganesha Jurusan Akuntansi Program S1, 8 No 2 (2017)

Plastrik, David Osborn dan peter, Memangkas Birokrasi (Jakarta: PT. PPM, 2018)

Priyanti, Dwi, 'Sistem Informasi Data Penduduk Pada Desa Bogoharjo Kecamatan Ngadirojo Kabupaten Pacitan', IJNS - Indonesian Journal on Networking and Security, 2013

Risnawan, Wawan, 'Profesionalisme Perangkat Desa Dalam Pengelolaan Keuangan Desa', Dinamika: Jurnal Ilmiah Administrasi Negara, 6.2 (2016), 50-56

Sitorus, E.B., Anselmus Tan, Suprayitno, Eko Prasetyanto, Christiani R. Tarigan, Sutoro Eko, and others, 'Naskah Akademik Rancangan Undang-Undang Tentang Desa', Naskah Akademik Rancangan UndangUndang, 2007, 1-98<www.forumdesa.org >

Soekanto, Soerjono, Pengantar Penelitian Hukum (Jakarta: UI Press)

Sofyanoor, Andin, 'Pengaturan Desa Dalam Perspektif Law As an Allocative System', FIAT JUSTISIA:Jurnal Ilmu Hukum, 8.2 (2015), 221-41 <https://doi.org/10.25041/fiatjustisia.v8no2.293>

Sunggono, Bambang, Penelitian Hukum (Jakarta: PT Raja Grafindo Persada, 2003)

Sunny, Ismail, Pergeseran Kekuasaan Eksekutif (Jakarta: Aksara Baru, 1986)

Wahidullah, jumaiyah dan, 'PEMBENAHAN PENGELOLAAN KEUANGAN DANA DESA: STUDI KASUS

DESA SENGONBUGEL', Media Riset Akuntansi, Auditing \& Informasi 19, 19.1 (2019), 19-34 